\title{
PENGARUH MODEL PEMBELAJARAN KOOPERATIF TIPE GALLERY WALK TERHADAP HASIL BELAJAR PADA PELAJARAN EKONOMI KELAS $X$ DI SMA NEGERI 1 PERBAUNGAN
}

\author{
Yuni Mariani Manik ${ }^{1)}$, Darwin Bangun ${ }^{2)}$ \\ Prodi Pendidikan Guru Sekolah Dasar, FKIP Universitas Efarina \\ yunimariani92@gmail.com
}

\begin{abstract}
This study aims to determine the effect of cooperative learning gallery walk type on learning outcomes of class X1 students in SMA Negeri 1 Perbaungan as well as an overview of student learning outcomes after the application of the learning model. This study used a Pre-Experimental Research Design The one Pretest-posttest Design group with a population of all students in class X1 Perbaungan 1 High School, amounting to 30 students. Because the population is relatively small so that samples are taken as much as $100 \%$ of the population, the number of samples in this study are 30 students (One Experimental Class). Data collection is done by using questionnaires, tests, observations, and documentation. The data analysis technique used is descriptive statistical analysis and inferential statistical analysis. The results showed that the walk gallery type cooperative learning model had a correlation of 0.782 in the medium category with a simple regression analysis equation $Y=-12.507+$ $1.641 X$. The results of hypothesis testing with SPSS obtained tcount $=6.640$ and ttable of 2.048 with a calculated value abel t table with a value of $6.640 \geq 2.048$ with a significance value of 0.000 so $\mathrm{H1}$ is accepted and $\mathrm{HO}$ is rejected, this indicates that the influence of the gallery walk type cooperative learning model on results studying class XI Negeri 1 Perbaungan students. The magnitude of the contribution of the influence of the learning model is 61.2 percent, while 38.8 percent is influenced by other factors that have not been studied in this study.
\end{abstract}

Keyword: Gallery Walk, Economic Lessons

\begin{abstract}
Abstrak
Penelitian ini bertujuan untuk mengetahui pengaruh model pembelajaran kooperatif tipe gallery walk terhadap hasil belajar sisiwa kelas X1 SMA Negeri 1 Perbaungan serta gambaran hasil belajar siswa setelah penerapan model pembelajaran tersebut. Penelitian ini menggunakan Desain Penelitian Pre-Eksperimen The one Grup Pretest-posttest design dengan populasi adalah seluruh siswa kelas X1 SMA Negeri 1 Perbaungan, yang berjumlah 30 siswa. Karena jumlah populasi yang relative kecil sehingga dilakukan penarikan sampel sebanyak $100 \%$ dari populasi maka jumlah sample pada penelitian ini sebanyak 30 siswa (Satu Kelas Eksperimen). Pengumpulan data dilakukan dengan cara menggunakan angket, Tes, observasi, dan dokumentasi. Teknik analisis data yang digunakan adalah analisis statistic deskriptif dan analisis statistic inferensial. Hasil penelitian menunjukkan bahwa model pembelajaran kooperatif tipe gallery walk memiliki korelasi sebesar 0,782 berada pada kategori sedang dengan persamaan analisis regresi sederhana $\mathrm{Y}=-12,507+1,641 \mathrm{X}$. Hasil uji hipotesis dengan SPSS diperoleh $\mathrm{t}_{\text {hitung }}=6,640$ dan $\mathrm{t}_{\text {tabel }}$ sebesar 2,048 ini berarti $\mathrm{t}_{\text {hitung }} \geq$ $t_{\text {tabel }}$ dengan nilai $6,640 \geq 2,048$ dengan nilai signifikansi 0,000 sehingga $\mathrm{H} 1$ diterima dan $\mathrm{H} 0$ ditolak, hal ini menunjukkan bahwa dapat pengaruh dari penggunaan model pembelajaran kooperatif tipe gallery walk terhadap hasil belajar siswa kelas X1 Negeri 1 Perbaungan. Besarnya kontribusi pengaruh model pembelajaran tersebut adalah 61,2 persen, sedangkan 38,8 persen tersebut dipengaruhi faktor-faktor lain yang belum dikaji dalam penelitian ini.
\end{abstract}

Kata Kunci : Gallery Walk, Pelajaran Ekonomi 


\section{PENDAHULUAN}

Kehidupan manusia tidak terlepas dari adanya pendidikan, baik yang berasal dalam keluarga, masyarakat maupun sekolah. Hasbullah (2013:1) mengatakan bahwa "dalam arti sederhana pendidikan sering diartikan sebagai usaha manusia untuk membina kepribadiannya sesuai dengan nilai-nilai di dalam masyarakat dan kebudayaan". Pendidikan dasar atau pendidikan awal yang didapatkan anak adalah pendidikan akhlak, sifat, dan pandangan hidup keagamaan yang sebagian besar dari dalam keluarga, sementara itu sebagai lanjutan dari pendidikan dalam keluarga, setiap anak berhak mendapatkan kesempatan untuk mendapatkan pendidikan di sekolah sebagai jembatan bagi anak yang menghubungkan antara kehidupan dalam keluarga dengan kehidupan di masyarakat kelak.

Sekolah merupakan salah satu lembaga pendidikan formal yang didalamnya terdapat proses belajar mengajar, Uno (2009:15) mengatakan "dalam proses kegiatan belajar dan mengajar peserta didik dijadikan sebagai student centered atau dalam kata lain pembelajaran berpusat pada peserta didik. Proses pembelajaran yang berlangsung lebih mengaktifkan peserta didik dibandingkan pendidik". Sanjaya dalam Lestari (2010:3) mengemukakan bahwa "Kegiatan belajar yang terjadi di sekolah tidak akan berjalan tanpa adanya peserta didik, karena peserta didiklah yang membutuhkan pengajaran dari seorang pendidik".

Untuk menciptakan proses belajar mengajar yang terarah diperlukan model pembelajaran yang menyenangkan yang dapat membangkitkan minat siswa dalam belajar. Salah satunya adalah model pembelajaran kooperatif. Inti dari pembelajaran adalah pembelajaran siswa secara berkelompok. Melalui kelompok, siswa akan membentuk diskusi, mengerjakan tugas bersama, saling membantu dan mendukung ketika diberikan masalah yang harus didiskusikan.

Namun melihat keadaan yang ada sekarang tampaknya pembelajaran ekonomi yang dilaksanakan belum cukup optimal. Salah satu penyebabnya karena dalam pelaksanaan pembelajaran terdapat permasalahan yang mendasar seperti peserta didik yang kurang aktif dalam pembelajaran ataupun kurangnya pemahaman peserta didik terhadap materi pembelajaran sehingga pada akhirnya hasil belajar yang selama ini dijadikan sebagai pedoman untuk mengukur tingkat keberhasilan pembelajaran menjadi tidak memuaskan.

Hal yang serupa terjadi di SMA Negeri 1 Perbaungan dimana proses pembelajaran yang berlangsung tentunya tidak luput dari ketidak sesuaian dengan pembelajaran yang diharapkan. Berdasarkan informasi yang didapatkan dari guru mata pelajaran Ekonomi dalam pelaksanaan pembelajaran Ekonomi pada kelas $\mathrm{X}$ sebagian besar hasil belajar peserta didik tidak menunjukkan adanya peningkatan yang disebabkan model pembelajaran yang terkesan monoton.

Beranjak pada penjelasan di atas peneliti berpendapat bahwa penggunaan model pembelajaran yang kurang efektif merupakan faktor utama yang memicu timbulnya masalah-masalah tersebut. Sehingga pertanyaan yang kemudian muncul adalah bagaimana cara pendidik untuk menciptakan suatu proses pembelajaran yang dinamis dan terkesan variatif. Bagaimana pembe-lajaran tersebut lebih banyak memberikan kesempatan kepada pendidik untuk berinteraksi dengan peserta didik lainnya, saling berdiskusi dan melontarkan pendapat sehingga peserta didik secara aktif terlibat dalam kegiatan pembelajaran, melalui proses pembelajaran tersebut peserta didik dapat memahami materi yang diajarkan sehingga hasil belajar yang dicapai peserta didik sesuai dengan yang diharapkan.

Salah satu alternatif untuk mengatasi masalah yang ada yaitu berupa penerapan model pembelajaran yang lebih mengutamakan keaktifan peserta didik dan memberikan kesempatan peserta didik untuk mengembangkan potensinya secara maksimal. 
Model pembelajaran yang dimaksudkan adalah model pembelajaran kooperatif.

Dalam model pembelajaran kooperatif terdapat beberapa tipe, salah satunya adalah model pembelajaran Gallery Walk yang dapat diterapkan dalam pembelajaran ekonomi. Secara etimologi, Gallery Walk berasal dari bahasa Inggris, Gallery artinya pameran, serambi. Pameran merupakan kegiatan untuk memperkenalkan produk, karya atau gagasan kepada khalayak ramai. Misalnya pameran gambar, pameran tulisan, dan pameran buku. Sedangkan Walk adalah berjalan, melangkah. Berdasarkan uraian tersebut, gallery walk (galeri belajar) merupakan salah satu bentuk model pembelajaran kooperatif yang mampu meningkatkan kemampuan Peserta didik untuk menemukan pengetahuan baru, dan mempermudah daya ingat karena sesuatu yang ditemukan itu dilihat secara langsung. Gallery Walk (galeri belajar) juga dapat memotivasi kehadiran peserta didik dalam proses belajar, sebab bila sesuatu yang baru ditemukan berbeda antara satu dengan yang lainnya maka dapat saling mengoreksi antara sesama peserta didik baik kelompok maupun antar peserta didik itu sendiri.

Setelah melakukan observasi awal dan wawancara kepada guru ekonomi di SMA Negeri 1 Perbaungan mengatakan bahwa guru masih menggunakan model pembelajaran konvensional pada umumnya yaitu ceramah diselingi tanya jawab dan pemberian tugas. Permasalahan yang lain yaitu partisipasi siswa yang kurang aktif dalam pembelajaran. Hal ini ditandai dengan banyaknya nilai kelas $\mathrm{X}$ yang tidak tuntas. Berdasarkan hasil observasi, terlihat hasil belajar mata pelajaran ekonomi siswa kelas $\mathrm{X}$ relatif rendah. Pola pembelajaran yang digunakan adalah pola pelaksanaan tuntas, ketuntasan minimal KKM untuk pembelajaran ekonomi yang diterapkan sekolah adalah 75. Dapat dilihat siswa $\mathrm{X}_{1}$ yang memiliki tingkat ketuntasan rendah yaitu 17 siswa yang tuntas dari jumlah siswa 36 dalam satu kelas. Masih terdapat siswa yang belum mencapai ketuntasan minimal (KKM) yaitu 75 dan mencapai angka yang tinggi, hampir setengah dari jumlah siswa kelas $\mathrm{X}_{1}$. Ini menjadi suatu masalah karena dengan hasil belajar siswa yang rendah membuktikan bahwa siswa belum mampu menguasai pelajaran.

Berdasarkan uraian diatas dapat disimpulkan bahwa model pembelajaran kooperatif tipe gallery walk dalam kaitannya dengan permasalahan pembelajaran yang terjadi pada kelas $\mathrm{X}_{1}$ dianggap menarik untuk diterapkan karena model pembelajaran tersebut berusaha meningkatkan kemampuan peserta didik baik secara kelompok maupun individu, mempermudah daya ingat peserta didik dalam mengingat materi, juga dapat memotivasi peserta didik baik dalam kehadiran maupun motivasi saat mengikuti proses pembelajaran.

Berdasarkan latar belakang yang ada telah diuraikan tersebut di atas, maka yang menjadi rumusan masalah dalam penelitian ini adalah sebagai berikut :

a. Bagaimanakah penerapan model pembelajaran kooperatif tipe gallery walk pada mata pelajaran ekonomi kelas $\mathrm{X}_{1}$ SMANegeri 1 Perbaungan?

b. Bagaimanakah hasil belajar siswa pada mata pelajaran ekonomi kelas $\mathrm{X}_{1}$ SMA Negeri 1 Perbaungan?

c. Apakah model pembelajaran kooperatif tipe gallery walk mempunyai pengaruh yang signifikan terhadap hasil belajar siswa pada mata pelajaran ekonomi kelas $\mathrm{X}_{1}$ SMA Negeri 1 Perbaungan?

Berdasarkan rumusan masalah yang telah di uraikan, maka yang menjadi tujuan dari penelitian ini adalah :

a. Untuk mengetahui gambaran penggunaan model pembelajaran kooperatif tipe gallery walk pada mata pelajaran ekonomi kelas $\mathrm{X}_{1}$ SMANegeri 1 Perbaungan.

b. Untuk mengetahui hasil belajar siswa 
pada mata pelajaran ekonomi kelas $\mathrm{X}_{1}$ SMANegeri 1 Perbaungan.

c. Untuk mengetahui pengaruh model pembelajaran kooperatif tipe gallery walk terhadap hasil belajar siswa pada mata pelajaran ekonomi kelas $\mathrm{X}_{1}$ SMA Negeri 1 Perbaungan.

\section{Pengertian Belajar}

Menurut (Slameto, 2010 : 2) belajar ialah suatu proses usaha yang dilakukan seseorang untuk memperoleh suatu perubahan tingkah laku yang baru secara keseluruhan, sebagai hasil pengalamannya sendiri dalam interaksi dengan lingkungannya. Sebagai hasil belajar, perubahan yang terjadi dalam diri seseorang berlangsung secara kesinambungan yang akan menyebabkan perubahan berikutnya.

Bila dianalisis pengertian belajar tersebut di atas, mengandung unsur-unsur yang sama, yaitu: (1) Belajar itu merupakan suatu kegiatan yang disadari dan mempunyai tujuan, (2) Proses belajar itu mengakibatkan perubahan tingkah laku, dan perubahan itu disebabkan oleh pengalaman-pengalaman atau latihan-latihan, dan bukan disebabkan oleh pertumbuhan atau kematangan, dan (3) Perubahan tingkah laku dalam belajar sifatnya menetap. Belajar dapat pula diartikan secara luas dan secara sempit. Secara luas, belajar diartikan sebagai kegiatan psikofisik menuju perkembangan pribadi seutuhnya. Secara sempit, belajar diartikan sebagai usaha penguasaan materi pelajaran.

\section{Teori Belajar}

Setiap teori mempunyai keunggulan dan kelemahan masing-masing sehingga dalam pelaksanaannya perlu menggabungkan beberapa teori agar saling melengkapi. Beberapa teori yang dapat kita jadikan acuan pada penelitian ini antara lain:

a. Teori Belajar Konstruktivisme

Teori konstruktivisme ini menyatakan bahwa siswa harus menemukan sendiri dan mentransformasikan informasi kompleks, mengecek informasi baru dengan aturanaturan lama dan merevisinya apabila aturanaturan itu tidak lagi sesuai.

b. Teori Perkembangan KognitifPiaget

Teori perkembangan viaget mewakili dari kontruktivisme yaitu memandang perkembangan kognitif sebagai suatu proses dimana anak secara aktif membangun system makna dan pemahaman realitas melalui pengalaman-pengalaman dan interaksi mereka. Teori ini jelas bahwa siswa harus aktif dalam mata pelajaran ekonomi sesuai dengan tingkat pemahaman mereka setelah mendapat pengetahuan secara realita dan sesuai dengan tingkatpengalamannya untuk menuangkan gagasan siswa dalam memecahkan permasalahan.

c. Teori Belajar John Dewey

Menurut John Dewey metode reflektif dalam memecahkan masalah yaitu suatu proses berpikir aktif, berhati-hati yang dilandasi proses berpikir kearah kesimpulankesimpulan yang dinitif.

d. Teori Pemrosesan Informasi

Teori ini menjelaskan pemrosesan, penyimpanan, dan pemanggilan kembali pengetahuan dari otak. Peristiwa-peristiwa mental diuraikan sebagai transformasitransformasi informasi dari input (stimulus) ke output (respon).

\section{Faktor Yang Mempengaruhi Belajar}

Keberhasilan siswa dalam belajar dipengaruhi oleh banyak faktor. Menurut (Slameto, 2010, 60-71) mengatakan ada dua faktor yang mempengaruhi belajar. Faktor tersebut yaitu faktor intern dan faktor ekstern.Faktor intern adalah faktor yang ada dalam diri individu yang sedang belajar, sedangkan faktor ekstern adalah faktor yang ada diluar individu.

a. Faktor intern meliputi, faktor jasmaniah, meliputi: kesehatan dan cacat tubuh, faktor 
psikologis, meliputi: intelegensi, perhatian, minat, bakat, motif, faktor kelelahan, meliputi: kelelahan jasmani dan kelelahan rohani.

b. Faktor Ekstern meliputi, faktor keluarga, meliputi: cara orang tua mendidik, relasi keluarga

c. Faktor Sekolah, meliputi: model mengajar, kurikulum

d. Faktor Masyarakat, meliputi: kegiatan siswa dalam masyarakat.

\section{Model Pembelajaran Kooperatif}

Pembelajaran kooperatif berbeda dengan pembelajaran yang lain. Perbedaan tersebut dapat dilihat dari proses pembelajaran yang lebih menekankan kepada proses kerja sama dalam kelompok. Tujuan yang ingin dicapai tidak hanya kemampuan akademik dalam pengertian penguasaan bahan pelajaran, tetapi juga adanya unsure kerja sama untuk penguasaan materi tersebut. Adanya kerja sama inilah yang menjadi ciri khas dari pembelajaran Kooperatif.

Pembelajaran Kooperatif sebagai bagian dari model pembelajaran memiliki karakteristik yang berbeda dengan model pembelajaran yang lainnya. Perbedaan tersebut dapat dilihat dari proses pembelajaran yang lebih menekankan proses kerjasama dalam kelompok. Sanjaya, (2012: 244-246) mengutarakan empat karakteristik pembelajaran kooperatif, yaitu “(1) Pembelajaran Secara Tim, (2) Didasarkan pada manajemen kooperatif, (3) Kemauan untuk Bekerja Sama, (4) Keterampilan Bekerja Sama”.

Berdasarkan uraian diatas dapat dipahami bahwa dalam pembelajaran kooperatif dalam pelaksanaannya menjadikan peserta didik yang beragam kemampuan akademiknya, jenis kelamin, dan latar belakang sosial membentuk suatu kelompok yang bekerja satu sama lain, saling bertukar pikiran, dan saling menuntun untuk mencapai tujuan belajar.

\section{Pembelajaran Kooperatif Tipe Gallery Walk}

Secara etimologi, Gallery Walk berasal dari bahasa Inggris, Galler yartinya pameran, serambi.Pameran merupakan kegiatan untuk memperkenalkan produk, karya atau gagasan kepada khalayak ramai. Misalnya pameran gambar, pameran tulisan dan pameran buku sedangkan walk adalah berjalan, melangkah. Selain itu, Gallery Walk atau Galeri belajar adalah suatu model pembelajaran yang mampu meningkatkan kemampuan peserta didik untuk menemukan pengetahuan baru dan dapat mempermudah daya ingat karena sesuatu yang di temukan itu dilihat secara langsung. Model ini baik digunakan untuk membangun kerja sama (cooperative learning). Gallery Walk juga dapat memotivasi keaktifan peserta didik dalam proses belajar, sebab bila sesuatu yang baru ditemukan berbeda antara satu dengan yang lainnya maka dapat mengoreksi antar sesama Peserta didik baik kelompok maupun antar Peserta didik itu sendiri.

Dengan menggunakan Gallery Walk diharapkan dapat teratasi kendala-kendala pembelajaran seperti materi pelajaran yang sulit diserap oleh peserta didik secara tidak maksimal. Karena metode ini dapat menghemat efisiensi waktu pelajaran dan Peserta didik lebih mudah memahami pelajaran. Gallery Walk memberikan kesempatan kepada peserta didik untuk membuat suatu karya dan melihat hasil karya kelompok yang lain sehingga dapat saling mengisi kekurangannya itu.

Jadi, Model Pembelajaran Gallery Walk merupakan model pembelajaran yang dapat diterapkan untuk semua mata pelajaran dan tingkatan kelas serta memberikan kesempatan kepada masing-masing anggota kelompok untuk menuangkan ide, serta gagasannya untuk menyempurnakan hasil kerja kelompoknya, serta mendengarkan saran maupun kritik dari anggota kelompok 
lainnya, dengan peran-peran khusus tiap anggota tim atau kelompok yang telah dibagi untuk bertanggung jawab atas tugas yang diberikan oleh ketua tim atau kelompok.

\section{Tujuan Pembelajaran Kooperatif Tipe Gallery Walk}

Gallery Walk sebagai salah satu metode pembelajaran bertujuan untuk mengatasi kendala-kendala pembelajaran, dan untuk meningkatkan motivasi serta keaktifan peserta didik dalam proses belajar mengajar. Saiful (2014: 9) tujuan-tujuan lain dari model pembelajaran gallery walk adalah sebagai berikut:

1. Menarik peserta didik ke dalam topik yang akan dipelajari

2. Memberikan kesempatan kepada peserta didik untuk menunjukkan pengetahuan dan keyakinan mereka tentang topik yang akan dibahas.

3. Mengajak peserta didik menemukan hal yang lebih dalam dari pengetahuan yang sudah mereka peroleh.

4. Memungkinkan Peserta didik mengembangkan pengetahuan dan keterampilannya (seperti berpikir, meneliti, berkomunikasi dan bekerjasama) dalam mengumpulkan informasi baru.

5. Memberi kesempatan kepada Peserta didik untuk memilah, mengolah dan menyajikan informasi dan pemahaman baru yang diperoleh.

6. Memberi kesempatan kepada Peserta didik untuk menentukan sendiri cara mendemonstrasikan hal yang telah dipelajari (pemahaman, keterampilan, sikap dan nilai).

Berdasarkan uraian diatas dapat disimpulkan bahwa motode pembelajaran gallery walk memiliki tujuan agar peserta didik mampu untuk mengembangkan pengetahuan dan keterampilannya, serta memberikan kesempatan kepada peserta didik untuk mengolah dan mendemostrasikan hal yang telah dipelajari berdasarkan topik yang telah ditentukan oleh pendidik.

\section{Komponen Metode Pembelajaran Gallery Walk}

Hal-hal yang harus diperhatikan sebelum diterapkannya Metode Pembelajaran Gallery Walk yaitu ketersediaan Komponenkomponen yang harus ada seperti yang dipaparkan berikut ini:

Menurut Saiful (2014: 9-10) ada beberapa komponen dalam pemakaian metode GalleryWalk. Komponen-komponen tersebut adalah:1) Pendidik, sebagai seorang pengajar (Pendidik) harus paham betul tentang metode Gallery Walk. 2) Peserta didik, dalam kegiatan belajar mengajar peserta didik mempunyai latar belakang yang berbeda-beda. Hal ini perlu dipertimbangkan dalam pemakaian Gallery Walk. 3) Alat / bahan, bahan yang disiapkan adalah kertas plano/ flip chart dan spidol.

Berdasarkan Uraian diatas dapat diketahui bahwa komponen yang harus ada dalam penerapan metode pembelajaran gallery walk yaitu pendidik yang harus memahami metode dan materi pembelajaran sebelum pembelajaran, Peserta didik sebagai sasaran penerapan metode pembelajaran gallery walk, serta alat dan bahan yang digunakan seperti kertas plano/flip chart harus tersedia sebelum menerapkan model pembelajaran gallerywalk.

\section{Langkah-langkah Penerapan Metode Pembelajaran Gallery Walk}

Dalam metode pembelajaran Gallery Walk Peserta didik diharapkan untuk menghargai dan mengapresiasi hasil karya orang lain. Langkah-langkah penerapan metode pembelajaran juga dirancang untuk menyenangkan dan membuat peserta didik termotivasi dan aktif dalam proses belajar mengajar.

Menurut Ismail dalam Siti (2009: 10) 
langkah-langkah Penerapan Model Gallery Walk antara lain:

1. Peserta didik dibagi dalam beberapa kelompok. Masing-masing kelompok terdiri dari empat sampai lima peserta didik.

2. Masing-masing dari kelompok diberi kertas plano / flipchart oleh pendidik.

3. Tentukan topik atau tema pelajaran.

4. Hasil kerja kelompok ditempel di dinding.

5. Masing-masing kelompok berputar mangamati hasil kerjakelompok lain.

6. Salah satu wakil kelompok menjelaskan setiap apa yangditanyakan oleh kelompok lain.

7. Koreksi bersama-sama.

8. Klarifikasi dan penyimpulan.

Berdasarkan uraian diatas dapat disimpulkan bahwa langkah-langkah penerapan metode pembelajaran gallery walk atau keliling kelompok umumnya dimulai dengan pembagian kelompok, kemudian pemberian salah satu komponen dari metode pembelajaran ini yaitu berupa kertas plano/flipchart dan spidol, menentukan tema yang akan dibahas, pemajangan hasil kerja kelompok kemudian akan dinilai oleh tiaptiap kelompok lainnya, penjelasan oleh salah satu anggota kelompok atas apa yang ditanyakan dari kelompok lain, adanya koreksi secara bersama, dan klarifikasi serta penyimpulan.

\section{Hasil Belajar}

Pengertian hasil belajar

Hasil belajar merupakan perubahan perilaku yang diperoleh pembelajar setelah mengalami aktivitas belajar. Perolehan aspek-aspek perubahan perilaku tersebut tergantung pada apa yang dipelajari oleh pembelajar. Oleh karena itu, apabila pembelajar mempelajari pengetahuan tentang konsep, maka perubahan perilaku yang diperoleh adalah berupa penguasaan konsep.Dalam pembelajaran, perubahan perilaku yang harus dicapai pembelajar setelah melaksanakan aktivitas belajar dirumuskan dalam tujuan pembelajaran (Anni, 2009: 5).

Hasil belajar merupakan salah satu indicator keberhasilan proses pembelajaran yang diterapkan pada siswa khususnya dan sekaligus indicator untuk menilai kualitas system pendidikan yang diterapkan pada umumnya. Hasil belajar manusia tampak dari perubahan aspek pengetahuan, pengertian, kebiasaan, keterampilan, apresiasi, emosional, hubungan IPS, jasmani, etis/budi pekerti, dan sikap. Menurut William Burton dalam Hamalik (2001: 31), hasil belajar adalah pola-pola perbuatan, nilai-nilai, pengertian-pengertian, sikap-sikap, apresiasi, abilitas, dan keterampilan. Hasil belajar diterima murid apabila member kepuasan pada kebutuhannya dan berguna serta bermakna baginya. Hasil-hasil belajar dilengkapi dengan jalan serangkaian pengalamanpengalaman yang dapat dipersamakan dan dengan pertimbangan-pertimbangan yang baik.Hasil-hasil belajar yang telah dicapai adalah bersifat kompleks dan dapat berubahubah (adaptable), jadi tidak sederhana dan statis.

\section{Fungsi hasil belajar}

Hasil belajar berfungsi sebagai hasil evaluasi atau penilaian akhir dari proses belajar pada suatau periode tertentu. Hasil belajar dapat berfungsi untuk mengetahui seberapa tingkat pengetahuan yang kita terima selama proses belajar. Dengan mengetahui hasil belajar kita dapat mengevaluasi diri kita. Jika nilai kita rendah, maka evaluasi yang perlu kita lakukan yaitu dengan lebih bersungguh-sungguh dalam menerima pelajaran dan lebih giat belajar. Jika nilai kita sudah mencapai criteria ketuntasan nilai maka kita perlu untuk mempertahankan nilai kita, bahkan lebih meningkatkan nilai kita menjadi lebih baik lagi. 


\section{Tinjauan Pembelajaran Ekonomi}

Gambaran umum ilmu ekonomi

Menurut Prof. P. A. Samuelson, seorang ahli ekonomi mengemukakan definisi ilmu ekonomi secara rinci, yaitu : "Ilmu Ekonomi adalah suatu studi mengenai bagaimana orang-orang dan masyarakat membuat pilihan, dengan cara atau tanpa penggunaan uang, dengan menggunakan sumber daya yang terbatas tetapi dapat digunakan dalam berbagai cara untuk menghasilkan berbagai jenis barang dan jasa dan mendistribusikannya untuk keperluan konsumsi sekarang dan di masa mendatang, kepada berbagai orang dan golongan masyarakat. Ilmu ekonomi menganalisis biaya dan keuntungan dan memperbaiki corak penggunaan sumbersumber daya.

Ilmu ekonomi adalah ilmu yang mempelajari perilaku manusia dalam memilih dan menciptakan kemakmuran. Inti masalah ekonomi adalah adanya ketidakseimbangan antara kebutuhan manusia yang tidak terbatas dengan alat pemuas kebutuhan manusia yang jumlahnya terbatas. Permasalahan tersebut kemudian menyebabkan timbulnya kelangkaan. Menurut Mankiw, ilmu ekonomi adalah studi tentang bagaimana masyarakat mengelola sumber daya yang selalu terbatas dan langka.

Secara umum ilmu ekonomi adalah salah satu cabang ilmu pengetahuan yang mempelajari tentang bagaimana manusia memenuhi kebutuhan hidupnya yang bersifat tidak terbatas dengan jumlah alat pemuas kebutuhan yang bersifat terbatas.Peneliti mengkategorikan tingkat efektivitas pembelajaran ekonomi dari hasil belajar sebagai berikut:

1) Sangat efektif apabila nilai rata-rata hasil belajar seluruh siswa dalam satu kelas adalah 100 .

2) Efektif apabila nilai rata-rata hasil belajar seluruh siswa dalam satu kelas adalah 75-99
3) Tidak efektif apabila nilai rata-rata hasil belajar seluruh siswa dalam kelas adalah kurang dari 75.

\section{METODE PENELITIAN Variabel Penelitian}

Variabel yang dikaji dalam penelitian ini adalah "Kooperatif tipe Gallery Walk terhadap hasil belajar". Variable yang digunakan yaitu

a. Kooperatif tipe Gallery Walk sebagai variabel bebas ( $\mathrm{X}$ ) atau variabel yang mempengaruhi.

b. Hasil belajar ekonomi siswa sebagi variabel terikat ( Y ) atau variabel yang dipengaruhi.

\section{Desain Penelitian}

Desain penelitian yang digunakan dalam penelitian ini adalah penelitian eksperimen. Penelitian eksperimen adalah pendekatan kuantitatif untuk menguji hubungan sebab akibat. Penelitian eksperimen dimaksudkan untuk mengumpulkan informasi atau data tentang akibat dari adanya Treatment atau perlakuan.Penelitian eksperimen dilakukan untuk mengetes suatu hipotesis yang dilandasi dengan asumsi yang kuat adanya hubungan sebab akibat antara dua variable.

\section{Populasi dan Sampel}

Populasi

Suharsimi (2006: 13) populasi adalah keseluruhan subjek penelitian. Populasi yang digunakan dalam penelitian ini adalah seluruh siswa kelas X SMA Negeri 1 Perbaungan tahun ajaran 2016/2017 yang berjumlah 174 siswa.

Sampel

Berkaitan dengan penentuan sampel Arikunto (2010) mengatakan bahwa : “Apabila subyek kurang dari 100, maka lebih 
baik diambil semua, sehingga penelitiannya merupakan peneliti populasi. Selanjutnya, jika subyeknya besar, dapat diambil antara 10 persen -15 persen atau 20 persen -25 persen atau lebih".

Dalam hal ini, pengambilan sampel dilakukan dengan teknik Purposive Sampling, yaitu teknik pengambilan sampel dilakukan berdasarkan pertimbangan perorangan atau peneliti. Pada hal ini, seorang ahli yang dimintai saran dalam menentukan dua kelas yang akan dijadikan sampel adalah guru ekonomi kelas $\mathrm{X}$ yang mengajar di SMAN 1 Perbaungan. Berdasarkan pertimbangan peneliti dan guru mitra maka diambil kelas X1 dan kelas X2, karena kedua kelas tersebut memiliki kemampuan akademik dan jumlah siswa yang tergolong sama. Setelah diperoleh dua kelas maka ditentukan kelas eksperimen dan kelas kontrol yang pada akhirnya, ditentukan kelas $\mathrm{X} 1$ sebagai kelas eksperimen dengan jumlah 36 siswa yang menggunakan model pembelajaran Kooperatif tipe Gallery Walk dan kelas X2 sebagai kelas kontrol dengan jumlah 36 siswa yang menggunakan metode pembelajaran konvensional.

\section{Teknik Pengumpulan Data}

Adapun teknik pengumpulan data yang digunakan dalam penelitian ini adalah:

1. Observasi

2. Tes

3. Dokumentasi

4. Kuesioner

Teknik Analisis Data

1. Analisis Statistik deskriptif

2. Analisis statistic inferensial

\section{HASIL DAN PEMBAHASAN}

Gambaran penggunaan Penerapan model pembelajaran Tipe Gallery Walk Pada Mata Pelajaran Ekonomi

Hasil olah data menggunakan Angket penelitian ini digunakan untuk mengukur keaktifan belajar, menonjolkan kemampuan individu dan mengasah kemampuan kognitif, afektif dan psikomotorik untuk mengukur bagaimana model pembelajaran Tipe Gallery Walk dinilai siswa sebagai faktor pembantu dalam membantu pemahaman siswa. Akumulasi jawaban siswa dari Angket mengenai model pembelajaran Tipe Gallery Walk diterapkan dalam mata pelajaran ekonomi adalah sebagai berikut : sebanyak 6 responden menjawab dengan kategori sangat tinggi berada pada interval 72-75 atau setara dengan 20 persen, sedangkan untuk kategori tinggi terdapat 6 responden yang menjawab berada pada interval 68-71 dengan persentase 20 persen. Terdapat 10 Responden yang menjawab pada kategori sedang, ini setara dengan 33,33 persen dan berada pada interval 64-67 untuk kategori rendah jumlah responden yang menjawab adalah 7 berada pada interval 60-63 dengan persentase sebesar 23,23 persen sedangkan pada kategori sangat rendah responden yang menjawab sebanyak 1 responden berada pada interval $<59$ dengan persentase sebesar 3,33 persen.

Dengan demikian dapat disimpulkan bahwa penerapan model pembelajaran Tipe Gallery Walk berada pada interval 64-67 dengan persentase 89,33 persen berada pada kategori "sedang". Berada pada kategori sedang mengenai persepsi siswa atau responden mengenai penerapan model pembelajaran Tipe Gallery Walk selaras dengan pendapat Asmani dalam Siti (2009: 8),

Menurut Asmani(2009:8),

"Model pembelajaran ini mempunyai tujuan agar masing-masing anggota kelompok mendapat kesempatan untuk memberikan kontribusi mereka dan mendengarkan pandangan serta pemikiran anggota lainnya.

Sejalan dengan pendapat Asmani adalah model pembelajaran Gallery Walk yang mengadaptasi kemampuan siswa untuk dapat mencapai prestasi belajar melalui kemampuan kerja sama dengan kelompok 
serta mengasah kemampuan masing-masing dalam kelompok. Kemampuan individual siswa dilihat dari cara dia menyampaikan pengetahuannya dari segi pengetahuan dan keterampilan bicara. Pendapat siswa mengenai kemampuan individu dipertanyakan dalam butir pertanyaan angket yang dibagikan.

Model pembelajaran ini menekankan pentingnya kontribusi masing-masing individu dalam kelompoknya. Sehingga kerja sama dalam kelompok dapat lebih aktif dan keterampilan masing-masing individu pun dapat diasah secara maksimal. Lebih lanjut lagi Slavin (2005:256), menjabarkan manfaat dari penerapan model pembelajaran ini yaitu. Menurut Slavin (2005:256) :

Model pembelajaran gallery walk merupakan salah satu model pembelajaran kooperatif yang meminta agar tim-tim atau kelompok peserta didik membuat sebuah pembelajaran, essay tertulis, menggambar sebuah mural, mengerjakan sebuah lembar kegiatan, dan melakukan presentasi di depan kelas, bagilah peran-peran khusus tiap anggota tim atau wilayah tanggung jawab individualnya.

Berdasarkan pendapat di atas dapat disimpulkan bahwa penerapan model pembelajaran gallery walk sangat efektif jika diiringi dengan penngunaan teknik kerja kelompok atau grup diskusi dalam pembelajaran. Hal ini bertujuan untuk mengasah kemampuan afektif dan psikomotorik siswa dalam pembelajaran. Ciri-cirinya dapat ditandai dalam hal adanya keberanian siswa dalam mengemukakan pendapatnya diantara teman-teman kelompoknya maupun dihapan teman-temannya yang lain. Selain itu, kemampuan kerja sama siswa juga mampu meningkat seiring meningkatnya keterampilan berbicara siswa didepan umum dalam hal ini didepan teman-temannya.

Gambaran Peningkatan Hasil Belajar Siswa Menurut Sudjana (2008), "Hasil belajar adalah kemampuan-kemampuan yang dimiliki siswa setelah menerima pengalaman belajarnya". Pengalaman belajar yang dimaksudkan adalah setelah penerapan kolaborasi model pembelajaran dimana dalam proses pembelajaran guru memberikan pertanyaan untuk setiap siswa secara investigasi seseuai dengan materi dan kemudian melihat bagaimana siswa mampu untuk menginterpretasikan apa yang dia ketahui dalam bentuk jawaban lisan. Jadi daalam proses pembelajaran yang dinamakan sebagai pengalaman belajar siswa diasaha secara langsung dan dinilai secara langsung mengenai pemahaman terhadap materi hasil dari penilaian secara proses pembelajaran akan diakumulasikan dengan hasil tes pada akhir pembelajaran.

Sehingga peningkatan hasil belajar tidak monoton pada satu referensi peneilaian saja yakni berdasarkan tes akhir tetapi berdasarkan pula akumuslasi penilaian proses dan penilaian akhir. Berikut akumulasi penilaian siswa dari pemberian prestest, penilaian proses, posttest dan nilai akhir siswa akumulasi dari nilai proses dan posttest : menunjukkan nilai rata-rata siswa dari Pre test, penilaian proses pembelajaran dan Posttest mengalami perubahan dari rerata 50 setelah Pre test hingga mencapai nilai rerata Post test 85,33 tetapi, yang menjadi pembanding adalah hasil Preetest dibandingkan dengan akumulasi penilaian dari Penilaian proses belajar dan penilaian Posttest. Dimana dalam hal ini, penilaian proses belajar diambil sebesar $40 \%$ dan penilaian hasil posttest diambil sebesar $60 \%$.

Sehingga, dalam penilaian akhir tidak terjadi kesenjangan antara kemampuan individual siswa dalam proses pembelajaran dengan kemampuan individual siswa dalam mengerjakan soal ujian. Hasil rerata Prestest menunjukkan sebelum pemberian materi kepada siswa dan penerapan model pembelajaran Gallery Walk persentase siswa 
yang memiliki nilai diatas standar KKM hanya sebagian kecil saja, setelah perlakuan penerapan model pembelajaran Gallery Walk nilai sebagian besar siswa telah melapaui standar KKM Mata pelajaran Ekonomi yakni dengan rerata 83,093.

Keterkaitan penjelasan Teori dengan hasil Penelitian

Hasil penelitian pada uji t menunjukkan bahwa menunjukkan hasil olah data dengan menggunakan SPSS diperoleh nilai $t_{\text {nitumg }}$ sebesar 6,640 dan $\mathrm{t}_{\text {atol }}$ dengan df (n-2) sebesar 2,048. Persyaratan untuk diterima tidaknya suatu hipotesis yaitu apabila $t_{\text {nitus }} \leq t_{\text {tater }}$ maka Ho diterima dan $\mathrm{H}_{1}$ ditolak, sedangkan apabila $t_{\text {nitug }}$ $\geq \mathfrak{t}_{\text {tabl }}$ maka Ho ditolak dan $\mathrm{H}_{1}$ diterima dengan taraf signifikan $5 \%$ persyaratan diterima tidaknya hipotesis yaitu apabila nilai signifikansi < taraf signifikan 0,05 maka H1 diterima $\mathrm{H} 0$ ditolak begitupula sebaliknya.

Hasil analisis yang diperoleh dengan menggunakan SPSS 20 menunjukkan bahwa $\mathrm{t}_{\text {hitung }}=6,640$ dan $\mathrm{t}_{\text {tabel }}$ sebesar 2,048 ini membuktikan bahwa $t_{\text {hiumg }} \geq t_{\text {abol }}$ dengan nilai $6,640 \geq 2,048$ selain itu dengan nilai signifikansi $0,000 \leq$ dari taraf signifikan 0,05 sehingga H1 diterima dan H0 ditolak, sehingga disimpulkan terdapat "Pengaruh Model Pembelajaran Kooperatif Tipe Gallery Walk Terhadap Peningkatan Hasil Belajar Siswa X SMANegeri 1 Perbaungan".

Hal teserbut menjelaskan bahwa model pembelajaran Gallery Walk berpengaruh terhadap Hasil belajar dengan kontribusi variabel X (model pembelajaran Gallery Walk) menjelaskan variabel Peningkatan hasil belajar sebesar $61,2 \%$

Hasil yang diperoleh ini menunjukkan bahwa penggunaan model pembelajaran gallery walk sangat efektif dalam meningkatkan keaktifan belajar siswa yang bedampak juga terhadap hasil belajar siswa. Hal ini Sejalan penelitian yang dilakukan oleh Novianti (2017) dalam penelitannya yang berjudul "Pengaruh Metode Gallery Walk terhadap minat belajar siswa pada mata pelajaran biologi di SMA Muhammadiyah 2 Palembang". Dari penelitian tersebut diketahui bahwa terdapat pengaruh yang positif dari penggunaan metode gallery walk terhadap minat belajar siswa.

\section{PENUTUP \\ Simpulan}

Berdasarkan hasil analisis dan pembahasan yang telah dikemukakan diatas maka dapat ditarik simpulan sebagai berikut :

1. Penerapan model pembelajaran KooperatifTipe Gallery Walk didasarkan pada orientasi masalah, pengorganisasian kegiatan pemeblajaran, penyelidikan mandiri dan penyajian hasil pemahaman siswa, menunjukkan adanya peningkatan keaktifan siswa dalam proses pembelajaran serta keberanian untuk menonjolkan kemampuan individunya masing-masing.

2. Hasil belajar siswa setelah penerapan model pembelajaran kooperatif tipe gallery walk pada mata pelajaran ekonomi kelas $\mathrm{X}_{1}$ SMA Negeri 1 Perbaungan menunjukkan perubahan yang signifikan dilihat dari nilai hasil rerata Prestest sebelum pemberian materi dan model pembelajaran Tipe Gallery Walk persentase siswa yang memiliki nilai diatas standar KKM hanya sebagian kecil saja, setelah perlakuan penerapan model pembelajaran Tipe Gallery Walk nilai sebagian besar siswa telah melampaui standar KKM Mata pelajaran Ekonomi yakni dengan rerata 83,093.

3. Penerapan Model Pembelajaran Kooperatif Tipe Gallery Walk Terhadap Hasil Belajar Siswa Pada Mata Pelajaran Ekonomi Kelas $\mathrm{X}_{1}$ SMA Negeri 1 Perbaungan memiliki pengaruh yang signifikan dan positif, dengan kontribusi variabel $\mathrm{X}$ terhadap variabel $\mathrm{Y}$ sebesar $61,2 \%$. 


\section{Saran}

Setelah melihat hasil penelitian yang telah dilaksanakan, maka penulis menyarankan:

1. Bagi pendidik, diharap model pembelajaran ini dapat menjadi referensi yang dapat digunakan pada materi-materi yang berbeda selain itu lebih berani lagi dalam melakukan kolaborasi model pembelajaran sesuai dengan karakteristik siswa dan materi yang akan diajarkan.

2. Bagi pihak sekolah, diharapkan berperan aktif dalam membina guru-guru atau pendidik untuk lebih memberikan variasi lagi dalam kegiatan pembelajaran sehingga siswa tidak hanya monoton pada suatu keadaan dan kondisi pembelajaran semata.

3. Bagi peneliti, diharapkan agar dapat meningkatkan dan memperkuat hasil penelitian ini dengan mengadakan pengkajian pada model-model pembelajaran yang lainnya.

\section{DAFTAR PUSTAKA}

Akdon, dan Ridwan. (2009). Aplikasi statistika dan metode penelitian. Bandung: Dewa Ruci.

Arikunto. (2006). Prosedur penelitian suatu pendekatan praktek: Jakarta Renika Cipta.

Alfabeta, Slameto. (2003). Belajar Dan Factor-Faktor Mempengaruhinya. Jakarta. PT.Rineka Cipta.

Hamalik, Oemar. (2007). Dasar-dasar Pengembangan Kurikulum. Bandung: PT Remaja Rosda Karya
Hasbullah. (2013). Dasar-Dasar Ilmu Pendidikan. Edisi Revisi. Jakarta: PT. Gramedia Widiasarana Indonesia.

Namalik. (2009). Proses Belajar Mengajar. Bandung. Bumi Aksara.

Noviyanti, Deby. (2017). Pengaruh Metode Gallery Walk terhadap minat belajar siswa pada mata pelajaran biologi di SMA Muhammadiyah 2 Palembang. Skripsi. Universitas Islam Negeri Fatah Palembang.

Sugiyono. (2010). Metodologi Penelitian Kuantitatif Kualitatif. Bandung: Alfabeta.

Sanjaya, Wina. (2006) Strategi Pembelajaran Berorientasi Standar Proses Pendidikan. Jakarta: Kencana.

Slavin. (2005). Cooperative Learning : Teori, Riset Dan Praktik. Bandung: nusa media.

Sudjana, Anas. (2008). Pengantar evaluasi pendidikan. Jakarta: Raja Gravindo Persada

Sugiyono. (2010). Metode Penelitian Kuantitatif Kualitatif dan R\&D. Bandung:Alfabeta.

Uno, Hamzah, B. (2009). Profesi Kependidikan : Problema, Solusi Dan Reformasi Pendidikan Di Indonesia. Jakarta: Bumi Aksara.

Yusuf, Muri. (2013). Metode Penelitian (Kuantitatif, Kualitatif dan Penelitian Gabungan). Jakarta : Kencana Prenada 